\title{
POLA ASUH ORANG TUA DIFABEL TERHADAP ANAK YANG NORMAL
}

\author{
${ }^{1}$ Mohammad Faisal F., ${ }^{2}$ Syaifullah Syam, ${ }^{3}$ Wilodati \\ ${ }^{1} S M A$ Negeri 1 Mandirancan Kuningan \\ ${ }^{2}$ Dosen Prodi Pendidikan Sosiologi Universitas Pendidikan Indonesia \\ ${ }^{3}$ Dosen Prodi Pendidikan Sosiologi Universitas Pendidikan Indonesia \\ E-mail:vizhal@yahoo.co.id
}

\begin{abstract}
ABSTRAK
Penelitian ini dilatarbelakangi oleh keberadaan orang tua difabel ditengah perannya dalam menerapkan pola asuh terhadap anak yang normal. Keterbatasan yang dimiliki orang tua difabel menjadi tantangan yang harus dihadapi dalam menjalankan tugas pola asuh. Penelitian ini berusaha menggali penerapan pola asuh orang tua difabel. Penelitian ini menggunakan pendekatan kualitatif. Teknik pengumpulan data yang digunakan dalam penelitian ini adalah wawancara mendalam, observasi dan dokumentasi. Hasil dalam penelitian ini menunjukkan bahwa: (1) secara dominan orang tua difabel menggunakan dua pola asuh yakni pola asuh authoritarian dan pola asuh autoritative. (2) Orang tua difabel telah menjalankan perannya sebagai pendidik, pengawas, tokoh panutan, sahabat, inspirator dan motivor bagi anaknya. (3) Terdapat faktor pendukung pola asuh yang dominan yaitu faktor lingkungan. Faktor penghambat pola asuh yakni orang tua difabel tidak dapat mengawasi pergaulan anak secara penuh dan tidak dapat membantu kegiatan belajar anak secara maksimal. (4) Dalam mengatasi kendala pola asuh, orang tua difabel berupaya melakukan tindakan preventif, berkonsultasi dengan orang terdekat, dan meminta bantuan orang yang dipercaya.
\end{abstract}

Kata Kunci : Pola asuh, Orang tua difabel, Keluarga.

\section{PENDAHULUAN}

Keluarga merupakan institusi sosial terkecil dalam masyarakat. Keluarga terdiri dari anggota keluarga yaitu orang tua, anak dan anggota keluarga lainnya yang saling berinteraksi dan membentuk hubungan serta ikatan secara emosional. Keluarga terbentuk atas dasar ikatan perkawinan, darah ataupun adopsi. Dalam hal ini Duval (Andarmoyo, 2012, hlm. 3) mengemukakan bahwa "keluarga adalah sekumpulan orang dengan ikatan perkawinan, kelahiran dan adopsi yang bertujuan untuk menciptakan, mempertahankan budaya dan meningkatkan perkembangan fisik, mental, emosional serta sosial dari setiap anggota keluarga".

Keluarga merupakan institusi pertama yang mengemban kedudukan sebagai wadah atau sarana sosialiasi pertama bagi seorang anak. Hal ini sejalan dengan 
yang dikemukakan oleh (Goode, 2007, hlm. 3) bahwa "kedudukan utama setiap keluarga ialah fungsi pengantara pada masyarakat besar." Artinya dalam hal ini keluarga berperan sebagai sarana dasar sosialisasi bagi setiap individu sebelum terjun ke masyarakat. Didalamnya terjadi fase awal individu mengenal masyarakat dan belajar tentang segala hal sehingga mencapai titik yang menjadikan individu tersebut sebagai makhluk sosial.

Secara ideal peranan orang tua sangat besar dalam membantu jalannya fase awal tersebut. Orang tua pada fungsinya bertugas sebagai guru pertama bagi seorang anak yang mengajarkan anak untuk mengenal dirinya, memahami lingkungan, mengajarkan nilai dan norma, membantu proses perkembangan, dan membentuk kepribadian anak. Maka dari itu, pendidikan dan keluarga merupakan satu kesatuan yang tidak dapat dipisahkan. Pendidikan ibarat darah yang melekat dan terus mengalir dalam kehidupan keluarga. Melalui pendidikan yang baik dan benar dalam keluarga, orang tua sepatutnya dapat mengembangkan potensi anak secara maksimal, karena pada hakikatnya potensi anak itu tidak akan pernah mengalami perubahan dalam arti bahwa anak selalu dapat berpikir, merasa, bertindak dan dapat terus berkembang dari waktu ke waktu.

Berkenaan dengan pendidikan dalam keluarga, (Djamarah, 2014, hlm. 47) menjelaskan bahwa: "Konteksnya dengan tanggung jawab orang tua dalam pendidikan, maka orang tua adalah pendidik pertama dan model utama dalam kelurga. Bagi anak, orang tua adalah model yang harus ditiru dan diteladani. Sebagai model, orang tua seharusnya memberikan contoh yang terbaik bagi anak dalam keluarga. Sikap dan perilaku orang tua harus mencerminkan akhlak yang mulia."

Dalam proses menjalankan fungsi pendidikan keluarga, yang menjadi ujung tombaknya adalah penerapan pola asuh orang tua terhadap anaknya. Pola asuh didefinisikan sebagai keseluruhan pola tindakan dan interaksi antara orang tua dalam mengasuh anaknya yang berjalan secara konsisten dengan tujuan untuk membentuk kepribadian anak. Penerapan pola asuh antara satu keluarga dengan keluarga lain tentu tidaklah sama. Hal ini terjadi karena dipengaruhi oleh berbagai faktor latar belakang. Seorang ahli bernama (Edwards, 2006, hlm. 16) mengungkapkan bahwa "pola asuh orang tua dipengaruhi oleh tiga faktor, yaitu: faktor pendidikan, faktor lingkungan tempat tinggal dan faktor budaya masyarakat." Faktor tersebut sangat menentukan cara orang tua dalam memilih pola asuh yang akan diberikan terhadap anaknya. Pendidikan yang tinggi, lingkungan tempat tinggal yang baik, dan budaya masyarakat yang menjunjung tinggi nilai dan norma akan sangat mempengaruhi serta mendukung jalannya pola asuh orang tua.

Pemberian pola asuh akan maksimal ketika orang tua dapat bertindak secara tepat dan efektif. Artinya orang tua tidak hanya berperan sebagai pendidik saja yang secara terus menerus mengarahkan, mengatur dan mendikte anak, melainkan terkadang dalam waktu dan kondisi tertentu orang tua dapat memainkan perannya dengan penuh 
kelemahlembutan sebagai sahabat dari anak, wadah pendengar keluh kesah dan masalah anak serta pemberi motivasi bagi anaknya. Hal ini sangat penting sebab dengan orang tua yang dapat memainkan perannya secara baik dan positif akan membuat orang tua dapat dengan mudah memasuki kehidupan dan perkembangan anaknya sehingga dampaknya akan terbentuk suasana kedekatan yang hangat dan intensif antara keduanya. Ketika hubungan emosional telah terbentuk maka orang tua akan lebih mudah menerapkan pola asuhnya terhadap anak.

Akan tetapi pada kenyataannya tidak semua manusia dilahirkan dengan kesempurnaan. Ada diantara manusia yang sejak lahir atau pada saat masa perkembangan mengalami keterbatasan fisik. Hal ini menjadi masalah bagi manusia yang mengalami keterbatasan fisik atau dikenal dengan istilah penyandang difabel. Difabel adalah suatu istilah atau sebutan yang pada dewasa ini sudah mulai digunakan untuk mengganti kata penyandang cacat. Difabel sendiri didefinisikan sebagai orang yang mengalami keterbatasan fisik. Dengan kata lain para penyandang difabel bukan dipandang sebagai orang yang menyandang cacat, akan tetapi penyandang difabel pada saat ini lebih dipandang sebagai orang-orang yang memiliki kemampuan yang berbeda dengan orang lainnya. Dalam hal ini, (Effendi, 2009, hlm. 36) menjelaskan bahwa "aktivitas manusia dalam berinteraksi dengan lingkungan sekitar akan efektif apabila mengikutsertakan alat-alat indra yang dimiliki, seperti penglihatan, pendengaran, perabaan, pembau, pengecap, baik dilakukan secara sendiri-sendiri maupun bersama-sama." Dengan kata lain ketika salah satu atau lebih fungsi indra terganggu maka dampaknya akan berpengaruh terhadap indraindra yang lain. Konsekuensinya tidak dapat dipungkiri akan menghambat kemampuan manusia dalam berinteraksi dengan lingkungan sekitar. Dengan demikian penyandang difabel memiliki kemampuan yang berbeda, karena biasanya ketika salah satu indra tidak dapat berfungsi maksimal maka satu atau dua indra yang lain akan lebih dominan digunakan.

Penyandang difabel suatu saat akan menjadi orang tua yang mau tidak mau harus mampu memerankan tugas dan fungsinya sebagai orang tua meskipun memiliki kemampuan yang berbeda. Orang tua tunanetra tetap akan berusaha membina keluarga dan anaknya agar menjadi pribadi yang baik dan membanggakan orang tua.

Peneliti dalam studi pendahuluan mendapatkan temuan awal yang memberikan gambaran pola asuh orang tua difabel terhadap anak yang normal di Klinik Pijat Jarima Kelurahan Ledeng, Bandung, yaitu bahwa orang tua difabel dalam kesehariannya banyak menghabiskan waktu untuk bekerja di panti pijat, ratarata dalam satu hari orang tua difabel bekerja hingga lebih dari sepuluh jam. $\mathrm{Hal}$ ini tentu membuat kurangnya waktu untuk bersama dengan anak dan keluarga, yang kemudian berpengaruh juga terhadap kualitas dan jenis pola asuh yang diberikan kepada anak. Para orang tua difabel menginginkan anak yang mandiri dan bertanggungjawab. Orang tua difabel juga berharap dapat menghantarkan anaknya hingga gerbang pintu kesuksesan dengan berusaha 
memberikan pendidikan baik secara formal di jalur pendidikan sekolah maupun pendidikan dalam keluarga. Melalui usaha-usahanya, terlihat bahwa orang tua difabel menunjukkan kasih sayang yang begitu besar kepada anaknya.

Berdasarkan uraian-uraian masalah yang peneliti paparkan diatas, maka peneliti tertarik untuk melakukan penelitian studi deskriptif mengenai pola asuh orang tua difabel terhadap anak yang normal.

\section{METODE}

Penelitian ini menggunakan pendekatan kualitatif dengan metode deskriptif. Pendekatan kualitatif digunakan karena permasalahan pola asuh merupakan ranah kajian dari penelitian kualitatif yang tidak bisa di uji secara kuantifikasi melalui statistika. Peneliti berusaha memahami pola asuh orang tua difabel terhadap anak yang normal melalui kajian secara mendalam terhadap subjek penelitian, yang kemudian dideskripsikan melalui metode deskriptif dalam bentuk katakata dan bahasa pada konteks alamiah yaitu dengan menggambarkan kenyataan yang terjadi di lapangan secara utuh atau menyeluruh, karena jika dipisahkan maka kenyataan tersebut tidak dapat dipahami konteksnya.

Teknik pengumpulan data yang dilakukan dalam penelitian ini, meliputi wawancara mendalam, observasi dan studi dokumentasi. Adapun teknik analisis data yang digunakan melalui tiga tahap yakni reduksi data, penyajian data dan penarikan kesimpulan. Sedangkan untuk menguji keabsahan data pada penelitian ini digunakan teknik triangulasi yaitu triangulasi sumber data dan triangulasi teknik pengumpulan data.

\section{HASIL DAN PEMBAHASAN HASIL}

Pola asuh merupakan bagian yang sangat penting dalam sebuah keluarga. Orang tua memberikan pengarahan, pendidikan dan bimbingan terhadap anak yaitu melalui sistem pola asuh yang diterapkan. Pola asuh menjadi begitu penting karena dapat berdampak besar terhadap kepribadian anak. Ketika pola asuh dapat dilakukan dengan baik maka hasilnya akan berdamapak positif juga terhadap kepribadian anak. Pola asuh sendiri merupakan pola tindakan dan interaksi antara orangtua dalam mengasuh anaknya yang berjalan secara konsisten dengan tujuan untuk membentuk kepribadian anak yang baik, mandiri, sholeh, dan bermanfaat bagi agama, keluarga, dan masyarakat sesuai dengan harapan orang tua.

Berdasarkan hasil penelitian, ditemukan bahwa orang tua difabel telah berupaya menerapkan pola asuh terhadap anaknya. Meski memiliki keadaan fisik yang terbatas, mereka tidak pernah lelah untuk berusaha memberikan segalanya dalam pemenuhan kebutuhan anak, baik secara fisik maupun psikis. Orang tua difabel dari tiga keluarga yang menjadi subjek penelitian yaitu Keluarga WN, Keluarga AF, dan Keluarga DP selain berperan sebagai pemijat di Klinik Pijat Jarima juga berperan sebagai orang tua yang berupaya menerapkan pola asuh sesuai dengan kemampuannya.

Orang tua difabel dalam kesehariannya menjalankan pola asuh bersifat fleksibel. Bukan berarti 
tidak konsisten dengan prinsip pemilihan pola asuh, melainkan dapat menyesuaikan diri dengan kondisikondisi yang dihadapi orang tua khususnya terhadap perkembangan anak.

Orang tua difabel akan bersikap tegas bahkan keras ketika menghadapi hal-hal seperti dalam aspek pendidikan anak, pergaulan anak dan penyimpangan atau pelanggaran yang dilakukan oleh anak. Berdasarkan hasil wawancara dengan keluarga AF, Bapak AF menjelaskan bahwa dalam mendidik anak Bapak AF dan lbu IY sangat serius dan benar-benar menegakkan kedisiplinan. Mereka memberikan fasilitas privat kepada anaknya agar dapat lebih mudah memahami materi pelajaran. Mereka juga seringkali melakukan konsultasi kepada guru dari anaknya di sekolah, dengan tujuan untuk mengetahui perkembangan anaknya secara keseluruhan. Ibu IY menjelaskan bahwa terkadang la merasa kurang puas dalam mendidik anak karena tidak bisa membantunya secara maksimal dalam pelajaran. Akan tetapi la selalu berusaha dengan terus berkonsultasi dengan suami, guru sekolah dan guru privatnya.

Dalam wawancara lain, Ibu KN menjelaskan bahwa pada waktu dan keadaan tertentu la dapat menjadi lebih keras kepada anaknya, terlebih jika anak sudah mulai susah untuk diberikan arahan secara baik-baik. Salah satu contohnya adalah ketika melanggar aturan, jika masih satu atau dua kali melanggar, lbu KN mentolerir dan mengarahkannya dengan cara yang baik dan lemah lembut. Akan tetapi ketika terus menerus terjadi baru lbu $\mathrm{KN}$ memberikan ketegasan dengan bahasa yang lebih keras kepada anaknya. Hal ini dilakukan agar anak tidak menjadi pribadi yang manja sehingga tidak dapat mandiri kedepannya.

Hal ini berbeda dengan sikap orang tua ketika dalam keseharian menjadi sangat lemah lembut saat menghadapi diskusi ringan dengan anak, mendengarkan curhatan atau keluh kesah dan masalah anak serta mendengarkan keinginan atau citacita anak.

Berdasarkan hasil wawancara, lbu IY menjelaskan bahwa untuk pemenuhan kasih sayang, la selalu berupaya mendengarkan keluh kesah dan masalah yang dihadapi anak. Meskipun hal ini sepele, tetapi akan berdampak besar terhadap perkembangan kepribadian anak. Dengan kata lain, anak yang dibesarkan dengan penuh perhatian dan kasih sayang akan cenderung lebih menghargai orang tua, memiliki kedekatan emosional yang tinggi, dan lebih mudah untuk diberikan pengarahan oleh orang tua.

Berkaitan dengan peran orang tua, Orang tua difabel berusaha menjalankan perannya sebaik mungkin, agar anak merasakan kasih sayang, perlindungan, rasa nyaman dan aman sehingga merasa betah berada di rumah bersama keluarga. Meskipun dengan keadaan fisik yang terbatas, bukan menjadi halangan untuk mengajarkan kebaikan kepada anak. Berdasarkan hasil penelitian, Bapak WN menjelaskan bahwa orang tua harus mampu mengajarkan nilainilai dari kejadian yang dihadapi oleh keluarga. Hal ini bertujuan agar anak dapat mengambil hikmah dan belajar dari pengalaman yang sebenarnya. Disamping itu Bapak WN juga dalam perkembangan anak, mengontrol 
pergaulan anaknya sehari-hari. la mencari tahu dan mengamati dengan siapa saja anak bergaul. Ketika mulai terlihat adanya indikasi penyimpangan, la segera bertindak, dengan menjelaskan dampak buruknya agar anak tidak terbawa arus pergaulan yang tidak baik.

Sikap yang diajarkan oleh orang tua difabel dari sejak kecil akan berdampak besar terhadap kepribadian anak. Orang tua difabel berusaha membiasakan anaknya untuk hidup sederhana dan disiplin dengan tujuan agar dari kecil anak sudah mulai terbentuk pribadinya, karena masa kanak-kanak adalah masa yang sangat tepat untuk mendidik sebagai modal penanaman mental dan karakter anak.

Pada aspek pemenuhan kebutuhan ekonomi, orang tua difabel telah mampu mencari nafkah dan memenuhi kebutuhan anak dan keluarga. Hal ini dilakukan melalui bekerja sebagai pemijat sesuai dengan keahliannya. Berdasarkan hasil wawancara, orang tua dari tiga keluarga selalu berupaya memenuhi kebutuhan keluarga dengan kerja keras dan menjunjung tinggi profesionalitas kerja.

Pada aspek lainnya yaitu perlindungan dan kasih sayang, orang tua difabel tidak pernah lepas dalam memerhatikan keadaan anaknya. Berbagai kesibukan orang tua tidak menjadi halangan untuk orang tua difabel dekat dengan anak. Orang tua difabel juga selalu ingin mengetahui dan mengontrol perkembangan anak sehari-hari. Dari hasil wawancara, lbu KN memaparkan bahwa orang tua hendaknya cerdas dalam membagi waktu antara bekerja dan bersama anak. la memanfaatkan waktu di selasela istirahat untuk bertemu dan memerhatikan kondisi anaknya. Ibu $\mathrm{KN}$ juga berupaya untuk mengontrol kegiatan dan pergaulan anak agar tidak melebihi batas sehingga anak tetap mendapat perlindungan dari orang tua.

Orang tua difabel dalam
menjalankan melakukan pemenuhan aspek religius terhadap anak. Selain penanaman nilai-nilai keagamaan, orang tua difabel mengarahkan dan selalu mengingatkan anak untuk beribadah tepat waktu. Dari hasil wawancara secara umum, orang tua dari tiga keluarga mendidik anak untuk tepat waktu dalam beribadah meskipun sedang dalam kesibukan, bahkan terkadang orang tua mengajak anak untuk beribadah bersama. Pada sore harinya, orang tua mempercayakan guru agama di lingkungan tempat tinggal untuk mengajarkan anak mengaji dan mendalami agama. Kegiatan ini dilakukan secara konsisten dan bersama-sama oleh anak dari orang tua difabel

Kegiatan pola asuh merupakan keseluruhan pola tindakan antara orang tua dan anak yang didalamnya terjadi proses membimbing, mendidik, dan mengarahkan yang berlangsung secara konsisten dan terus menerus. Konsistensi pola asuh dapat tercapai ketika orang tua mendapatkan dukungan bukan hanya secara internal keluarga, melainkan juga melalui faktor-faktor eksternal di luar keluarga. Faktor pendukung pola asuh yaitu dipengaruhi oleh faktor pendidikan, faktor lingkungan tempat tinggal dan faktor budaya masyarakat.

Dari ketiga faktor tersebut, faktor yang paling dominan dalam mendukung penerapan pola asuh orang tua difabel adalah faktor lingkungan, khususnya lingkungan 
Klinik Pijat Jarima. Berdasarkan hasil wawancara dan observasi, Ibu DS menjelaskan bahwa lingkungan tempat tinggal sangat mendukung dalam mengasuh dan membimbing anak. la juga menjelaskan bahwa teman-teman pemijat tunanetra dan para pengurus Klinik Pijat Jarima tidak hanya fokus terhadap pekerjaannya masing-masing saja melainkan juga saling menjaga dan mengarahkan anak apabila terjadi sesuatu. Hal ini juga dikemukakan oleh Ibu KN, bahwa faktor yang sangat mendukung pola asuh adalah lingkungan tempat tinggal khususnya di lingkungan Klinik Pijat Jarima. Selain karena waktu antara orang tua difabel dan anak yang banyak dihabiskan di Klinik, teman-teman pemijat dan pengurus juga sangat peduli dengan keadaan anak. Mereka ikut memerhatikan kondisi anak, dan seringkali juga mereka khususnya para pengurus yang memiliki kesehatan dan penglihatan yang normal menjadi orang-orang yang dipercayai untuk membantu dan mengawasi kegiatan pergaulan anak sehari-hari.

Disamping itu terdapat faktor penghambat pola asuh. Faktor tersebut adalah faktor yang dilatarbelakangi oleh keterbatasan orang tua. Berdasarkan hasil wawancara dan observasi, Ibu KN menjelaskan bahwa hambatan yang paling terasa adalah dalam melakukan pengawasan terhadap kegiatan anak. Berdasarkan hasil wawancara lain, Bapak WN dan Bapak AF serta istrinya memiliki pendapat yang sama mengenai hambatan dalam memberikan pola asuh terhadap anak. Mereka menjelaskan bahwa hambatan utama dalam mengasuh anak dengan keadaan difabel tunanetra adalah dalam hal pendidikan yaitu tidak dapat maksimal membantu dan memberikan pelajaran tambahan diluar sekolah.

Hambatan atau kendala tersebut adalah hambatan yang khas yang hanya dihadapi oleh orang tua difabel. Maka untuk mengatasinya, orang tua difabel tidak hanya diam dan pasrah dengan keadaan. Mereka berupaya dengan kemampuannya mencari cara untuk mengatasi kendala dengan kemampuan yang dimiliki.

Berdasarkan hasil penelitian, Bapak MB sebagai ahli psikologi menjelaskan bahwa pada dasarnya orang tua tunanetra dapat berperan sebagaimana orang tua normal lainnya, sebab hasil dari pola asuh orang tua tunanetra dan orang tua normal dapat dikatakan sama. Tidak sedikit orang tua tunanetra memiliki anak yang sukses dan berhasil menjadi sosok yang dicita-citakan baik oleh anak sendiri maupun orang tua. Hanya yang membedakan adalah dalam aspek teknis pengasuhan.

Orang tua difabel berupaya mengatasi kendala pola asuh dengan melakukan tindakan preventif atau pencegahan, berdiskusi dengan orang-orang terdekat dan meminta bantuan orang lain sesuai dengan kapasitasnya.

\section{PEMBAHASAN}

Penerapan pola asuh orang tua terhadap anak adalah bagian dari fungsi keluarga. Keluarga hendaknya dapat menjalankan berbagai fungsinya agar tujuan dari pembentukan keluarga dapat tercapai. Setidaknya ada delapan fungsi keluarga menurut (Soelaeman, 1994, hlm. 85), diantaranya yaitu "fungsi edukatif, sosialisasi, protektif, afeksional, religius, ekonomis, rekreatif, dan biologis." Fungsi 
tersebut merupakan tugas dan tanggungjawab orang tua yang dilakukan secara beriringan.

Menjalankan sistem pola asuh sebenarnya juga telah menjalankan fungsi keluarga. Fungsi dalam teori fungsionalisme struktural menurut Parsons (Ritzer, 2014, hlm. 117) memiliki skema yang dikenal dengan sebutan AGIL. Skema AGIL diyakini oleh Parsons terdiri dari empat fase yaitu Adaptation, Goal Attainment, Integration, dan Latten Pattern Maitenance. Sistem pola asuh yang dibentuk oleh orang tua sangat berkaitan dengan skema AGIL tersebut.

Pada fase pertama yaitu Adaptation, sebuah sistem harus menanggulangi situasi eksternal yang gawat. Sistem harus menyesuaikan diri dengan lingkungan dan menyesuaikan lingkungan itu dengan kebutuhannya. Berdasarkan hasil wawancara dan observasi, orang tua difabel dalam penelitian ini memerankan tugasnya dengan baik. Orang tua difabel mengenalkan anak dengan nilai-nilai dan norma yang berlaku di lingkungan masyarakat. Mereka ingin anaknya dapat hidup baik dan rukun dengan masyarakat. Mereka juga ingin agar anak mampu beradaptasi dengan kondisi apapun yang terjadi di lingkungan.

Fase kedua yaitu Goal Attainment. Pada fase ini sebuah sistem harus mendefinisikan dan mencapai tujuan utamanya. Proses tingkah laku anak sangat dominan terlihat pada fase ini. Parsons berpandangan bahwa hal utama dalam struktur kepribadian berasal dari sistem-sistem sosial dan kebudayaan yang di internalisasi lewat sosialisasi. Anak-anak dari orang tua difabel setelah melalui proses adaptasi, mereka mulai menunjukkan sikap dan tingkah laku baik yang bersifat positif maupun sebaliknya. Dari pengenalan nilai-nilai yang dilakukan orang tua difabel dalam wadah sosialisasi terhadap anak, anak mulai memperlihatkan sikap dari apa yang ditangkap melalui proses sosialisasi.

Fase selanjutnya adalah fase Integration. Fase integrasi menunjukkan bahwa satu sistem harus mengatur antar-hubungan bagian-bagian yang menjadi komponennya. Sistem juga harus mengelola antar hubungan ketiga fungsi penting lainnya $(A, G, L)$. Dalam penelitian ini, orang tua difabel dan anak memiliki hubungan komunikasi yang baik. Mereka dikesehariannya terbiasa melakukan diskusi-diskusi mengenai hal-hal yang dihadapi. Orang tua ataupun anak bebas mengemukakan pendapat dan keinginannya namun tetap dalam batas norma yang ditetapkan. Melalui proses tersebut, kerjasama antar anggota keluarga terbentuk dengan baik.

Fase yang terakhir adalah fase Latensi. Pada fase latensi atau pemeliharaan pola, sebuah sistem harus melengkapi, memelihara dan memperbaiki, baik motivasi individual maupun pola-pola kultural yang menciptakan dan menopang motivasi. Pada fase ini, orang tua difabel dan anak saling memelihara suasana keutuhan dan keharmonisan keluarga serta saling memberikan bantuan dan motivasi. Kultur dalam keluarga juga sudah terpola dengan baik.

Berdasarkan hasil penelitian bahwa ketiga keluarga yang menjadi informan memiliki pola asuh yang tidak berbeda jauh. Hal ini dilatarbelakangi oleh faktor 
ketunanetraan dari orang tua. Orang tua difabel lebih dominan menggunakan pola asuh authoritative atau demokratis, dan pola asuh authoritarian atau otoriter. Dua jenis pola asuh tersebut dikombinasikan oleh orang tua difabel, dengan tujuan untuk saling melengkapi dalam kondisi-kondisi tertentu yang dihadapi orang tua.

Pola asuh authoritarian atau otoriter adalah pola asuh yang penerapannya berpusat pada orang tua. Pada pola asuh ini, orang tua memiliki kekuasaan untuk mengatur segala kegiatan yang dilakukan anak. Pendekatan yang dilakukan orang tua terhadap anak cenderung menggunakan pendekatan yang mengandung unsur paksaan dan ancaman. Hal ini sejalan dengan pandangan (Djamarah, 2014, hlm. 60) yang mengemukakan bahwa pola asuh otoriter adalah jenis pola asuh yang memaksakan kehendak. Orang tua cenderung sebagai pengendali dan pengawas, selalu memaksakan kehendak kepada anak, tidak terbuka, dan tidak menerima saran dan masukan dari anak.

Jenis pola asuh authoritarian atau otoriter digunakan orang tua difabel dalam hal pendidikan, pergaulan dan ketika anak melakukan penyimpangan atau pelanggaran yang berat. Dalam aspek pendidikan, orang tua difabel sangat mengutamakannya. Orang tua berupaya agar anak mendapatkan pendidikan terbaik bahkan hingga menghantarkannya ke jenjang perguruan tinggi. Sebagaimana keluarga berfungsi sebagai sarana pendidikan bagi seluruh anggota keluarga termasuk yang paling utama adalah terhadap anak.
Pola asuh authoritative atau demokratis adalah pola asuh yang memberikan ruang dan kebebasan kepada anak untuk mengemukakan pendapat, dan melakukan apa yang diinginkan anak namun tetap dalam batasan dan pengawasan orang tua. Pola asuh ini selalu mengutamakan kepentingan bersama diatas kepentingan individu anak atau orang tua. Orang tua dalam pola asuh demokratis selalu memberikan bimbingan dan arahan dengan penuh pengertian. Hal ini sejalan dengan pendapat yang dikemukakan oleh Baumrind (Santrock, 2007, hlm. 167) bahwa 'Pola asuh otoritatif atau demokratis adalah gaya pola asuh yang mendorong anak untuk mandiri, namun masih menempatkan batas kendali pada tindakan mereka.'

Berdasarkan hasil wawancara dan observasi, jenis pola asuh authoritative atau demokratis digunakan orang tua difabel seharihari ketika melakukan diskusi ringan dengan anak, mendengarkan keluh kesah yang dihadapi anak, serta mendengarkan keinginan atau harapan dan cita-cita anak. Para orang tua difabel di Klinik Pijat Jarima secara keseluruhan dalam komunikasi dengan anak sehari-hari memberikan ruang dan wadah bagi anak untuk bercerita mengenai masalah-masalah yang dihadapi. Hal ini dilakukan untuk mempermudah orang tua menjalankan peran dan fungsinya. Terlebih informasi yang diterima oleh orang tua difabel kebanyakan atau bahkan satu-satunya dari pendengaran, maka dari itu orang tua difabel sangat membutuhkan segala informasi, masukan, dan keluh kesah yang dihadapi anak agar orang tua lebih mudah mengawasi perkembangan anak dan lebih mudah 
juga dalam mengarahkan dan membimbing anak.

Orang tua memiliki beberapa peran yang harus dijalankan, seperti yang diungkapkan oleh (Hufad, 2000, hlm. 7) yakni "meliputi perannya sebagai pendidik, sebagai panutan atau contoh bagi anak-anaknya, sebagai pengawas, sebagai teman, serta sebagai pendorong dan sebagai inspirasi bagi anak."

Berdasarkan hasil wawancara dan observasi, diketahui bahwa orang tua difabel meski dengan keadaan fisik yang terbatas, selalu berusaha sebaik mungkin menjalankan perannya dalam mendidik anak. Orang tua difabel mulai mendidik anak semenjak kecil dengan menanamkan nilai-nilai yang berlaku dalam keluarga dan masyarakat. Penanaman nilainilai tersebut meliputi nilai kemandirian, nilai kesopanan, nilai kedisiplinan dan nilai tanggungjawab.

Sebagai orang tua, orang tua difabel dari masing-masing keluarga juga berupaya untuk menjadi contoh atau panutan bagi anak-anaknya. Meski dengan keadaan yang terbatas mereka berupaya sebaik mungkin dengan kemampuannya untuk dapat menjadi teladan bagi anak. Mereka selalu berusaha melakukan apapun demi kebaikan anak. Mereka beranggapan bahwa anak selalu menjadi prioritas utama dibandingkan dengan hal-hal penting lainnya. Bahkan orang tua difabel sangat ingin mencukupi kebutuhan anak dan keluarga.

Selain berperan sebagai pendidik dan panutan, orang tua difabel juga melaksanakan perannya sebagai pengawas, seperti yang diungkapkan oleh (Hufad, 2000, hlm. 7) bahwa "sebagai pengawas, pada fase perubahan, sangatlah kritis bagi perkembangan anak, oleh karena itu, posisi orang tua adalah menentukan dalam mengawasi proses perubahan yang dialami anak." Berdasarkan hasil observasi diperoleh bahwa orang tua difabel selalu mengawasi kegiatan anaknya. Pengawasan tersebut meliputi kegiatan megawasi, mengkontrol dan mengarahkan anak dalam berbagai aspek yang diperhatikan orang tua seperti pendidikan, pergaulan dan sikap atau perkembangan kepribadian anak. Tujuan dari diadakannya pengawasan ini adalah untuk melindungi dan mengkontrol segala hal yang dapat berpengaruh terhadap perkembangan anak.

Orang tua dalam keluarga memang terkadang dalam waktu dan kondisi tertentu harus berperan ganda, bahkan ada kalanya juga orang tua dapat berperan sebagai teman dari anaknya, sebagaimana diungkapkan oleh (Hufad, 2000, hlm. 7) bahwa "sebagai mahluk sosial, anak memerlukan kehadiran orang lain sebagai teman, orang tua merupakan orang yang paling dekat dengan anak." Berdasarkan hasil wawancara dan observasi orang tua difabel melaksanakan perannya sebagai teman dengan baik. Orang tua difabel selalu menyediakan waktu untuk mendengarkan masalah dan keluh kesah yang dihadapi anak. Orang tua difabel tidak pernah bosan hadir sebagai orang yang dapat mengerti dan memahami keadaan anak-anaknya.

Selanjutnya orang tua difabel juga menjalankan perannya sebagai pendorong dan inspirasi bagi anak. Setelah melakukan wawancara dan observasi diketahui bahwa dari masing-masing keluarga, orang tua difabel berupaya untuk selalu 
mendorong anak ke arah yang lebih baik dengan memberikan saransaran, motivasi, berusaha menjadi inspirasi bagi anak-anaknya. Upaya mendorong dan menjadi inspirasi dilakukan meliputi kegiatan diskusi ringan, bertukar pikiran, mengingatkan anak jika melakukan kesalahan, bercerita mengenai hikmah-hikmah dari kejadian yang telah dialami keluarga, serta memberi motivasi ketika anak mulai jenuh atau malas.

Setiap keluarga menjalankan pola asuhnya masing-masing sesuai dengan keadaan dan kebutuhan keluarga. Pola asuh dalam sebuah keluarga akan berjalan dengan baik ketika didukung oleh berbagai faktor yakni sebagaimana dikemukakan oleh (Edwards, 2006, hlm. 16) bahwa "faktor pendukung atau yang mempengaruhi pola asuh yaitu dari mulai faktor pendidikan, faktor lingkungan dan juga faktor budaya."

Berdasarkan hasil wawancara dan observasi, diperoleh bahwa ternyata dari masing-masing keluarga mendapatkan dukungan dari faktor pendidikan, faktor lingkungan tempat tinggal, dan faktor budaya dari lingkungan dalam melaksanakan pola asuh. Akan tetapi dari ketiga faktor tersebut, terdapat faktor yang paling dominan yaitu faktor lingkungan. Lingkungan tempat tinggal menjadi faktor yang sangat mendukung pola asuh orang tua difabel, sebagaimana yang diungkapkan oleh (Edwards, 2006, hlm. 16) bahwa "lingkungan banyak mempengaruhi dalam perkembangan anak, maka tidak mustahil jika lingkungan juga ikut serta mewarnai pola-pola pengasuhan yang diberikan orang tua terhadap anak."

Orang tua difabel dari ketiga keluarga sangat merasa terbantu oleh faktor lingkungan, khususnya lingkungan pekerjaan yakni Klinik Pijat Jarima. Klinik Pijat Jarima merupakan lingkungan yang sangat penting bagi orang tua dalam melaksanakan pola asuh karena pada kenyataannya hampir setiap hari penuh anak dan orang tua menghabiskan waktunya di klinik. Orang tua difabel merasa terbantu oleh lingkungan Klinik Pijat Jarima karena lingkungan ini memberikan suasana yang nyaman dan aman bagi orang tua dan anak. Lingkungan klinik sudah seperti keluarga besar dari orang tua difabel. Bukan hanya disebabkan karena orang tua difabel sudah bekerja dalam waktu yang lama sebagai pemijat di klinik, melainkan juga karena para pemijat dan pengurusnya yang ramah, sopan dan baik. Selain itu para pengurus dan pemijat juga sangat peduli dengan kondisi anak-anak dari orang tua difabel. Mereka ikut membantu jalannya pola asuh dengan ikut mengawasi kegiatan anak, mengarahkan anak dan membimbing anak dari orang tua difabel. Hal ini tiada lain karena para pekerja sudah seperti keluarga sendiri.

Disamping itu, selain faktor pendukung terdapat juga faktor yang menghambat jalannya pola asuh orang tua difabel terhadap anak. Faktor penghambat yang dialami oleh orang tua difabel yakni mengawasi kegiatan atau pergaulan anak dan membantu anak dalam belajar atau menyelesaikan tugas-tugas sekolah.

Hambatan utama yang dirasakan oleh orang tua difabel adalah dalam mengawasi kegiatan anak dan memberikan pelajaran tambahan kepada anak. Hal ini tidak terlepas dari ketunanetraan yang dialami orang tua. Orang tua yang tunanetra memiliki keterbatasan fisik 
yang tidak dapat dipungkiri sedikit banyaknya mempengaruhi aktivitas orang tua sehari-hari.

Dalam menghadapi kendala pola asuh, orang tua difabel tidak hanya berdiam diri dan menyerah dengan keadaan. Orang tua difabel melakukan berbagai upaya untuk dapat mengatasi kendala-kendala yang dihadapi. Meskipun dibekali dengan keadaan fisik yang terbatas, akan tetapi hal tersebut tidak menjadi alasan bagi mereka untuk memberikan pola asuh yang terbaik bagi anak-anaknya. Hal ini dapat menjadi tumpuan bagi orang tua untuk membimbing dan mengarahkan anak menjadi pribadi yang sukses, mandiri dan bertanggungjawab sesuai dengan harapan orang tua.

Berdasarkan hasil wawancara dan observasi, dapat disimpulkan bahwa terdapat tiga upaya yang dilakukan oleh orang tua difabel dalam mengatasi kendala pola asuh yakni melakukan tindakan preventif, berkonsultasi dengan orang lain, dan meminta bantuan orang yang dapat dipercaya.

Upaya yang pertama adalah dengan melakukan tindakan preventif terhadap kegiatan anak, baik dalam hal belajar, bermain, bergaul maupun dalam mengatur waktu atau jadwal kegiatan anak. Hal ini dilakukan melalui penjelasan yang diberikan orang tua terhadap anak sebelum sesuatu terjadi. Sesuatu yang dimaksud adalah kegiatan-kegiatan yang mengarah pada penyimpangan dan pelanggaran.

Upaya orang tua difabel yang kedua dilakukan melalui konsultasi dengan orang-orang terdekat yang dapat dipercaya. Hal ini dilakukan dengan cara bertukar pikiran dan meminta saran-saran terhadap orang- orang kepercayan dari orang tua difabel. Orang tua difabel seringkali ketika menghadapi masalah dalam pola asuh melakukan konsultasi dengan para pengurus dan rekan kerjanya di Klinik Pijat Jarima. Orang tua difabel bertukarpikiran dengan orang tua lainnya. Mereka saling bercerita dan memberi masukan satu sama lain mengenai masalahmasalah yang dihadapi.

Upaya orang tua difabel dalam mengatasi kendala pola asuh selanjutnya adalah meminta bantuan orang lain ketika mengalami kesulitan yang disebabkan oleh keterbatasan fisik. Dalam pembelajaran, orang tua banyak melakukan diskusi dengan guru anaknya. Hal ini dilakukan untuk mengetahui perkembangan anak dalam pembelajaran. Ketika anak mengalami kesulitan dalam pelajaran tertentu, orang tua segera mengetahuinya dari guru tersebut, sehingga dapat cepat tanggap mengatasinya dengan meminta bantuan orang lain seperti guru les atau mahasiswa yang tinggal di lingkungan sekitar yang berkenan membantu anak belajar ketika berada dirumah. Disamping itu dalam hal pengawasan terhadap kegiatan anak, orang tua meminta bantuan dari para pengurus Klinik Pijat Jarima yang memiliki penglihatan optimal. Para pengurus jarima dengan kepeduliannya selalu berupaya memantau pergaulan anak, kegiatan belajar anak, kegiatan ibadah anak, serta kegiatan lainnya yang tidak dapat dipantau secara penuh oleh orang tua. Mereka juga senantiasa bertindak mengarahkan dan membimbing anak dari orang tua difabel ketika melakukan kesalahan dan penyimpangan. 
Dengan demikian berdasarkan hasil penelitian, upaya-upaya yang dilakukan orang tua difabel merupakan bagian dari tindakan nyata orang tua difabel yang sangat menyayangi anaknya dan menginginkan anaknya menjadi pribadi yang sukses, baik, mandiri dan bertanggungjawab sesuai harapan orang tua.

\section{SIMPULAN}

Pertama, Terdapat kekhasan dari orang tua difabel dalam menjalankan pola asuh terhadap anaknya, yakni orang tua difabel cenderung menggunakan dua pola asuh yaitu Pola asuh authoritarian (otoriter) dan Pola asuh authoritative (demokratis) yang dikombinasikan dengan tujuan untuk saling melengkapi dalam kondisi-kondisi tertentu. Pola asuh authoritarian (otoriter) digunakan orang tua difabel dalam aspek pendidikan, pergaulan dan ketika anak melakukan penyimpangan atau pelanggaran yang berat. Sedangkan Pola asuh authoritative (demokratis) digunakan orang tua difabel sehari-hari ketika melakukan diskusi ringan dengan anak, mendengarkan keluh kesah yang dihadapi anak, serta mendengarkan keinginan atau harapan dan cita-cita anak.

Kedua, Orang tua difabel telah menjalankan perannya sebagai pendidik, pengawas, tokoh panutan, sahabat, inspirator dan sebagai motivor bagi anaknya. Hal itu dilakukan melalui perannya dalam memberikan pendidikan bagi anak dengan mengenalkan dan mengajarkan nilai-nilai kemandirian, kesopanan serta tanggungjawab. Disamping itu orang tua difabel juga berusaha selalu mengasawi kegiatan dan perkembangan anak secara penuh, berusaha menjadi contoh atau panutan yang dapat menjadi teladan bagi anak, mendengarkan keluh kesah dan masalah yang dihadapi anak, serta berupaya menjadi sosok inspirasi bagi anak yang senantiasa memberi saran, masukan dan motivasi bagi perkembangan anak.

Ketiga, Terdapat satu faktor dominan yang mendukung penerapan pola asuh orang tua difabel terhadap anak yang normal. Faktor tersebut adalah faktor lingkungan sebagaimana terlihat di lingkungan Klinik Pijat Jarima. Dalam hal ini pengurus dan pemijat klinik telah banyak mendukung dan membantu jalannya pola asuh orang tua difabel. Mereka selalu memerhatikan dan peduli dengan kondisi anak dari orang tua difabel. Disamping itu terdapat dua faktor yang menjadi penghambat pola asuh orang tua difabel yakni tidak dapat mengamati kegiatan dan pergaulan anak secara penuh serta tidak dapat membantu anak dalam aspek pembelajaran secara maksimal. Hal ini tiada lain dilatarbelakangi oleh keterbatasan fisik dari orang tua difabel.

Keempat, Terdapat tiga upaya yang dilakukan oleh orang tua difabel untuk mengatasi kendala pola asuh yakni yang pertama adalah dengan melakukan tindakan preventif kepada anak melalui pengarahan dampak baik dan buruknya sesuatu hal sebelum terjadi, yang kedua adalah melakukan konsultasi kepada orangorang terdekat mengenai masalah yang dihadapi dengan cara bertukar pikiran dan meminta masukan serta saran tentang masalah yang dahadapi, upaya yang ketiga yaitu dengan meminta bantuan orang lain yang dipercaya ketika memang orang 
tua sudah mengalami kesulitan yang berat seperti kepada para pengurus dan pemijat Klinik Pijat Jarima serta kepada guru sekolah atau guru les dari anaknya.

\section{DAFTAR RUJUKAN}

Andarmoyo, S. (2012). Keperawatan Keluarga. Yogyakarta: Graha IImu

Djamarah, S. B. (2014). Pola Asuh Orang Tua dan Komunikasi dalam Keluarga. Jakarta: Rineka Cipta

Edwards, D. (2006). Ketika Anak Sulit Diatur: Panduan Orang Tua Untuk Mengubah Masalah Perilaku Anak. Bandung: PT. Mizan Pustaka
Effendi. M. (2009). Pengantar Psikopedagogik Anak Berkelainan. Jakarta: Bumi Aksara

Goode, J. W. (2007). Sosiologi Keluarga. Jakarta: PT. Bumi Aksara.

Hufad. A. (2000). Peran Keluarga Inti dalam Mendidik Anak. Jurnal Pendidikan Luar Sekolah. 1, (1), hlm 61-67. Bandung: PLS, FIP, Universitas Pendidikan Indonesia

Ritzer, G (2014). Teori Sosiologi Modern. Jakarta: Kencana

Santrock, J. W. (2007). Perkembangan Anak. Jakarta : Erlangga

Soelaeman. M. I. (1994). Pendidikan dalam Keluarga. Bandung: Alfabeta 